\title{
Sistem Pakar Untuk Menentukan Poin Pelanggaran Dan Prestasi Menggunakan Inferensi Fuzzy (Tsukamoto)
}

Expert System for Determining Abuse and Achievements Points Using Fuzzy Inference (Tsukamoto)

\author{
Widatin Mayasari ${ }^{1}$, Agus Sidiq Purnomo ${ }^{2}$ \\ 1,2 Program Studi Teknik Informatika, Fakultas Teknologi Informasi, Universitas Mercu Buana Yogyakarta, Jl. \\ Wates Km. 10 Yogyakarta 55753, Indonesia \\ Email: widatinmayasari@gmail.com¹, sidiq@mercubuana-yogya.ac.id ${ }^{2}$
}

\begin{abstract}
ABSTRAK
Salah satu permasalahan yang ditemui dalam bidang pendidikan adalah bimbingan konseling. Untuk melakukan bimbingan konseling diperlukan layanan ahli oleh konselor (guru bimbingan dan konseling). Bimbingan konseling pada siswa menggunakan jumlah poin pelanggaran siswa yang telah ditetapkan oleh pihak sekolah. Penentuan poin pelanggaran siswa memerlukan beberapa kategori meliputi pelanggaran siswa, prestasi siswa dan sanksi pelanggaran. Dalam penentuan poin pelanggaran siswa maka dilakukan penelitian dengan mengimplementasi metode fuzzy Tsukamoto untuk menentukan poin pelanggaran siswa dengan beberapa kategori yang dijadikan dasar penentuan. Berdasarkan hasil pengujian dengan sistem dan perhitungan manual guru bimbingan konseling memiliki hasil 73,17\% sesuai.
\end{abstract}

Kata Kunci: Sistem Pakar; Bimbingan Konseling; Fuzzy Tsukamoto

\begin{abstract}
One of the problems encountered in education is counseling. To conduct counseling counseling requires expert services by counselors (guidance and counseling teachers). Counseling guidance on students using the number of student violation points set by the school. Determination of student violation points requires several categories including student offenses, student achievement and sanction offenses. In determining the points of violation of students then conducted research by implementing Tsukamoto fuzzy method to determine the points of violation of students with some categories that serve as the basis of determination. Based on the results of testing with the system and manual calculation of counseling teachers have a result of $73.17 \%$ according.
\end{abstract}

Keywords: Expert System; Counseling Guidance; Fuzzy Tsukamoto

\section{PENDAHULUAN}

Untuk menentukan kualitas pendidikan, bimbingan konseling menjadi faktor penentunya. Guru bimbingan konseling bertugas untuk mengawasi dan mengarahkan siswa. Setiap harinya guru menghadapi beragam karakter siswa yang berbeda-beda.

Terutama guru bimbingan konseling SMP Muhammadiyah 9 Yogyakarta yang masih memberikan sanksi pelanggaran kepada siswa-siswi SMP Muhammadiyah 9 Yogyakarta secara acak menurut pemikiran guru bimbingan konseling itu sendiri bukan berdasarkan pada aturan yang telah ditetapkan oleh sekolah.
Oleh karena itu diperlukan sebuah sistem pakar yang dapat membantu mencarikan solusi atas permasalahan pemberian sanksi secara acak kepada siswa-siswi sesuai dengan aturan yang telah ditetapkan oleh sekolah.

Bimbingan Konseling (BK) adalah pelayanan bantuan untuk peserta didik, baik secara perorangan maupun kelompok, agar mandiri dan berkembang secara optimal, dalam bimbingan pribadi, bimbingan sosial, bimbingan belajar, dan bimbingan karir, melalui berbagai jenis layanan dan kegiatan pendukung, berdasarkan normanorma yang berlaku (Priyolistiyanto \& Saefan, 2014). 
Bimbingan dan konseling bukanlah kegiatan pembelajaran dalam konteks adegan mengajar yang layaknya dilakukan guru sebagai pembelajaran bidang studi, melainkan layanan ahli dalam konteks memandirikan peserta didik. Oleh karena itu, bimbingan dan konseling merupakan layanan ahli oleh konselor (guru bimbingan dan konseling). Konselor adalah salah satu kualifikasi pendidikan, yaitu tenaga kependidikan, yaitu tenaga kependidikan yang memiliki kekhususan pada bidang bimbingan dan konseling, yang berpartisipasi dalam menyelenggarakan pendidikan (Kamaluddin, 2011).

Penilaian dalam BK yang digunakan terdapat dua poin yaitu : (1) poin pelanggaran, dan (2) poin prestasi.

Rumusan masalah dalam penelitian ini diantaranya adalah sebagai berikut : (1) Bagaimana merancang aplikasi sistem pakar penentuan poin pelanggaran siswa? (2) Bagaimana mengimplementasikan metode fuzzy Tsukamoto pada sistem pakar untuk menentukan poin pelanggaran dan poin prestasi siswa?

Tujuan dari penelitian ini yaitu merancang aplikasi sistem pakar penentuan poin pelanggaran siswa dan dapat mengimplementasikan metode fuzzy Tsukamoto pada sistem pakar menentukan poin pelanggaran dan prestasi pada siswa.

Manfaat dari penelitian ini yaitu membangun sistem penentuan poin pelanggaran siswa sehingga proses penentuan poin pelanggaran menjadi lebih cepat dan tepat.

\section{TINJAUAN PUSTAKA}

Beberapa penelitian yang terkait antara lain seperti pada penelitian mengenai pentingnya mengetahui letak kecerdasan yang paling menonjol pada anak sejak dini agar kualitas pendidikan dapat meningkat. Hal ini dilakukan supaya pendidikan yang diberikan lebih sesuai dengan minat dan bakat siswa. Pembuatan sistem pakar tentang diagnosis kecerdasan majemuk pada anak ini sangat membantu sekali dalam mendiagnosis bakat dan minat siswa (Setiawan, Jusak, \& Lemantara, 2013).

Sistem yang dibuat ini bertujuan untuk memprediksi kegagalan peralatan dengan memantau parameter pada peralatan dan penjadwalan pemeliharaan yang tepat sebelum terjadi kerusakan yang fatal. Berdasarkan hal tersebut maka dalam membangun sistem pakar untuk pemeliharaan preventif digunakan logika fuzzy yang mampu menangani ketidakjelasan dan ketidakpastian dari berbagai variabel pemeliharaan trafo. Logika fuzzy yang digunakan adalah sistem inferensi fuzzy tsukamoto karena metode ini menggunakan aplikasi nilai monoton (Thamrin, Sediyono, \& Suhartono, 2012).

Dalam menentukan sanksi, terkadang guru juga melakukan kesalahan dalam pemberian sanksi, dimana siswa yang melanggar peraturan yang sama namun menerima sanksi yang berbeda. Dalam penelitian ini, metode Fuzzy Tsukamoto digunakan untuk mencari nilai kepastian dari input yang berupa pelanggaran dan sebab terjadinya pelanggaran untuk menentukan sanksi kepada siswa yang melanggar peraturan akademik (Wana \& Winiarti, 2013).

Untuk mempermudah mengenali permasalahan yang dialami oleh siswa, maka dibutuhkan sebuah sistem yang dapat mewakili seorang pakar yang memiliki basis pengetahuan dan pengalaman tentang bimbingan dan konseling yaitu sebuah sistem pakar. Dengan dibangunnya sistem pakar berbasis web ini diharapkan dapat memberikan kemudahan dalam aktivitas akademik khususnya bimbingan dan konseling (Syah \& Gunawan, 2016).

Sedangkan dalam penelitian ini fokus terhadap pengembangan sistem pakar untuk menentukan poin pelanggaran siswa menggunakan metode fuzzy tsukamoto, dengan beberapa variabel yaitu pelanggaran, prestasi dan sanksi. Sistem ini ditujukan untuk membantu guru bimbingan konseling dalam melakukan penentuan poin pelanggaran pada siswa.

Sistem pakar adalah salah satu cabang ilmu AI (Artificial Intelligent) yang membuat penggunaan secara luas knowledge yang khusus untuk penyelesaian masalah tingkat manusia yang pakar. Seorang pakar adalah orang yang mempunyai keahlian dalam bidang tertentu, yaitu pakar yang mempunyai knowledge atau kemampuan khusus yang orang lain tidak mengetahui atau mampu dalam bidang yang dimilikinya (Arhami, 2005).

Metode Tsukamoto merupakan perluasan dari penalaran monoton, pada metode Tsukamoto, setiap konsekuen pada aturan yang berbentuk IF-Then harus direpresentasikan dengan suatu himpunan fuzzy dengan fungsi keanggotaan yang monoton. Sebagai hasilnya, output hasil inferensi dari tiap-tiap aturan diberikan secara tegas (crisp) berdasarkan $\alpha$ predikat (fire strength). Hasil akhirnya diperoleh dengan menggunakan rata-rata terbobot (Kusumadewi \& Purnomo, 2010). 


\section{METODOLOGI PENELITIAN}

Secara garis besar proses jalannya penelitian ini dibagi menjadi empat tahapan, yaitu : (1) Akuisisi Pengetahuan, (2) Representasi Pengetahuan, (3) Inferensi Pengetahuan dan (4) Pemindahan Pengetahuan. Flowchart jalannya penelitian dapat dilihat pada Gambar 1.

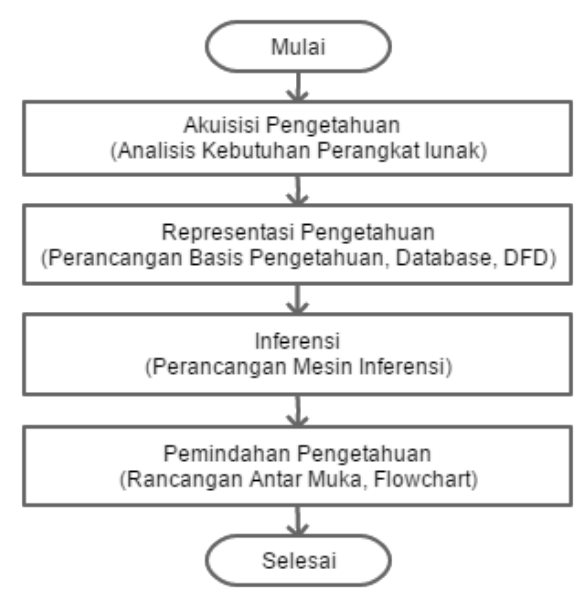

Gambar 1. Jalan Penelitian

\subsection{Akuisisi Pengetahuan}

Akuisisi Pengetahuan merupakan kegiatan untuk mencari dan mengumpulkan data untuk analisis kebutuhan perangkat lunak meliputi analisis kebutuhan masukan, analisis kebutuhan proses dan analisis kebutuhan keluaran.

\subsection{Representasi Pengetahuan}

\subsubsection{Perancangan Data Flow Diagram}

Data flow diagram Level 0 dalam penelitian ini dapat dilihat pada Gambar 2.

\subsubsection{Perancangan Basis Pengetahuan}

Perancangan basis pengetahuan pada fuzzy Tsukamoto meliputi variabel input, variabel keanggotaan dan basis aturan dapat dilihat pada Tabel 1 sampai Tabel 3.

Tabel 1. Variabel Input

\begin{tabular}{|c|c|}
\hline No & Nama Variabel \\
\hline 1 & Pelanggaran \\
\hline 2 & Prestasi \\
\hline
\end{tabular}

Tabel 2. Keanggotaan

\begin{tabular}{|c|c|c|c|c|c|}
\hline No & $\begin{array}{c}\text { Batas } \\
\text { Bawah }\end{array}$ & $\begin{array}{c}\text { Batas } \\
\text { Tengah }\end{array}$ & $\begin{array}{c}\text { Batas } \\
\text { Atas }\end{array}$ & Variabel & Keterangan \\
\hline $\mathbf{1}$ & 0 & 3 & 50 & Pelanggaran & $\begin{array}{c}\text { Ringan } \\
\text { Sekali }\end{array}$ \\
\hline $\mathbf{2}$ & 3 & 50 & 109 & Pelanggaran & Ringan \\
\hline $\mathbf{3}$ & 50 & 109 & 149 & Pelanggaran & Sedang \\
\hline $\mathbf{4}$ & 109 & 149 & 169 & Pelanggaran & Berat \\
\hline $\mathbf{5}$ & 149 & 169 & 189 & Pelanggaran & Berat Sekali \\
\hline $\mathbf{6}$ & 169 & 189 & 200 & Pelanggaran & $\begin{array}{c}\text { Sangat Berat } \\
\text { Sekali }\end{array}$ \\
\hline $\mathbf{7}$ & 0 & 2 & 12,5 & Prestasi & Kecil \\
\hline $\mathbf{8}$ & 2 & 12,5 & 25 & Prestasi & Sedang \\
\hline $\mathbf{9}$ & 12,5 & 25 & 25 & Prestasi & Besar \\
\hline
\end{tabular}

\subsubsection{Perancangan Database}

Relasi tabel dalam penelitian ini dapat dilihat pada Gambar 3.

\subsection{Inferensi Pengetahuan}

Dari perancangan sistem pendukung keputusan ini menggunakan metode inferensi Fuzzy Tsukamoto. Metode Fuzzy Tsukamoto dimulai dari pembentukan himpunan tiap variabel kemudian dilanjutkan menggunakan proses perhitungan inferensi dan terakhir proses defuzifikasi dengan perhitungan $z$-score untuk menentukan sanksi pelanggaran.

\subsection{Pemindahan Pengetahuan}

Perancangan jalannya sistem dapat dilihat pada Gambar 4. 


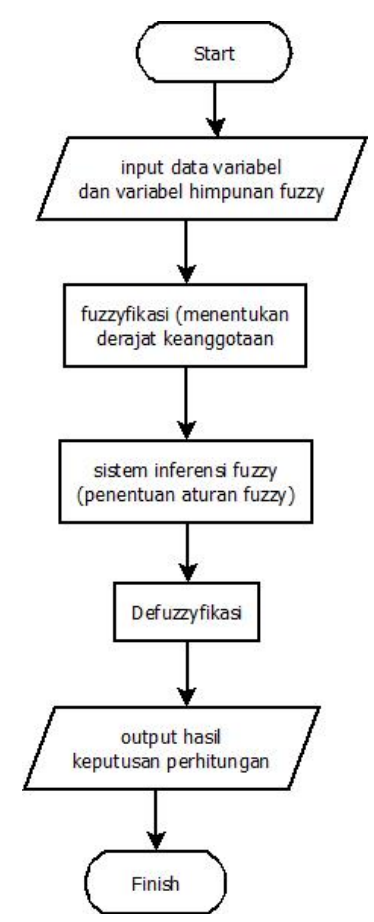

Gambar 2. Flowchart Sistem

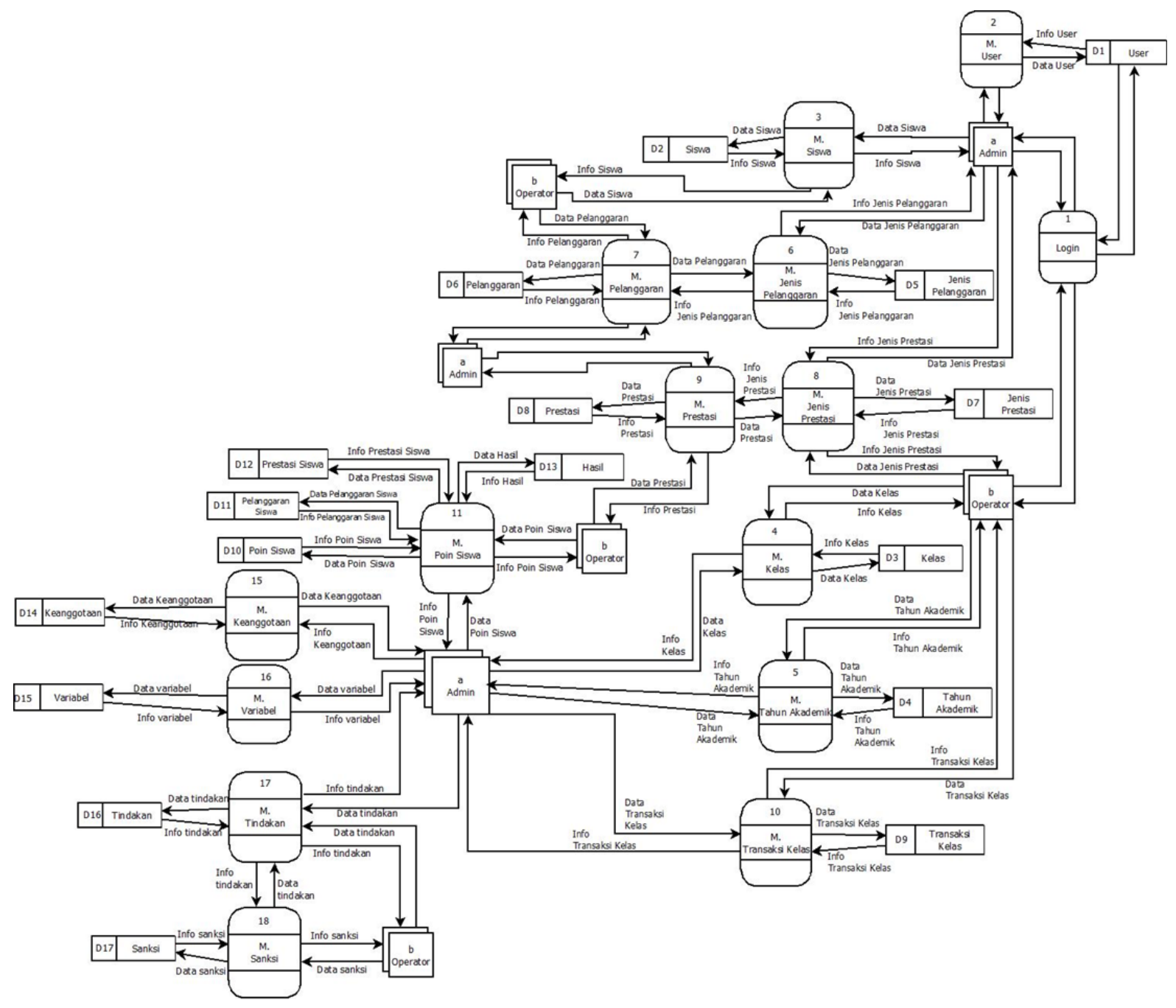

Gambar 3. Data Flow Diagram Level 0 
Tabel 3. Aturan Fuzzy

\begin{tabular}{|l|l|l|l|l|}
\hline No & \multicolumn{3}{|c|}{ PELANGGARAN and PRESTASI } & \multicolumn{1}{|c|}{ Sanksi } \\
\hline $\mathbf{1}$ & IF & RINGAN SEKALI and KECIL & THEN & Ringan Sekali \\
\hline $\mathbf{2}$ & IF & RINGAN SEKALI and SEDANG & THEN & Ringan Sekali \\
\hline $\mathbf{3}$ & IF & RINGAN SEKALI and BESAR & THEN & Ringan Sekali \\
\hline $\mathbf{4}$ & IF & RINGAN and KECIL & THEN & Ringan \\
\hline $\mathbf{5}$ & IF & RINGAN and SEDANG & THEN & Ringan \\
\hline $\mathbf{6}$ & IF & RINGAN and BESAR & THEN & Ringan \\
\hline $\mathbf{7}$ & IF & SEDANG and KECIL & THEN & Sedang \\
\hline $\mathbf{8}$ & IF & SEDANG and SEDANG & THEN & Sedang \\
\hline $\mathbf{9}$ & IF & SEDANG and BESAR & THEN & Sedang \\
\hline $\mathbf{1 0}$ & IF & BESAR and KECIL & THEN & Besar \\
\hline $\mathbf{1 1}$ & IF & BESAR and SEDANG & THEN & Besar \\
\hline $\mathbf{1 2}$ & IF & BESAR and BESAR & THEN & Sedang \\
\hline $\mathbf{1 3}$ & IF & BESAR SEKALI and KECIL & THEN & Besar Sekali \\
\hline $\mathbf{1 4}$ & IF & BESAR SEKALI and SEDANG & THEN & Besar Sekali \\
\hline $\mathbf{1 5}$ & IF & BESAR SEKALI and BESAR & THEN & Besar \\
\hline $\mathbf{1 6}$ & IF & SANGAT BESAR SEKALI and KECIL & THEN & Sangat Besar Sekali \\
\hline $\mathbf{1 7}$ & IF & SANGAT BESAR SEKALI and SEDANG & THEN & Besar Sekali \\
\hline $\mathbf{1 8}$ & IF & SANGAT BESAR SEKALI and BESAR & THEN & Besar Sekali \\
\hline
\end{tabular}
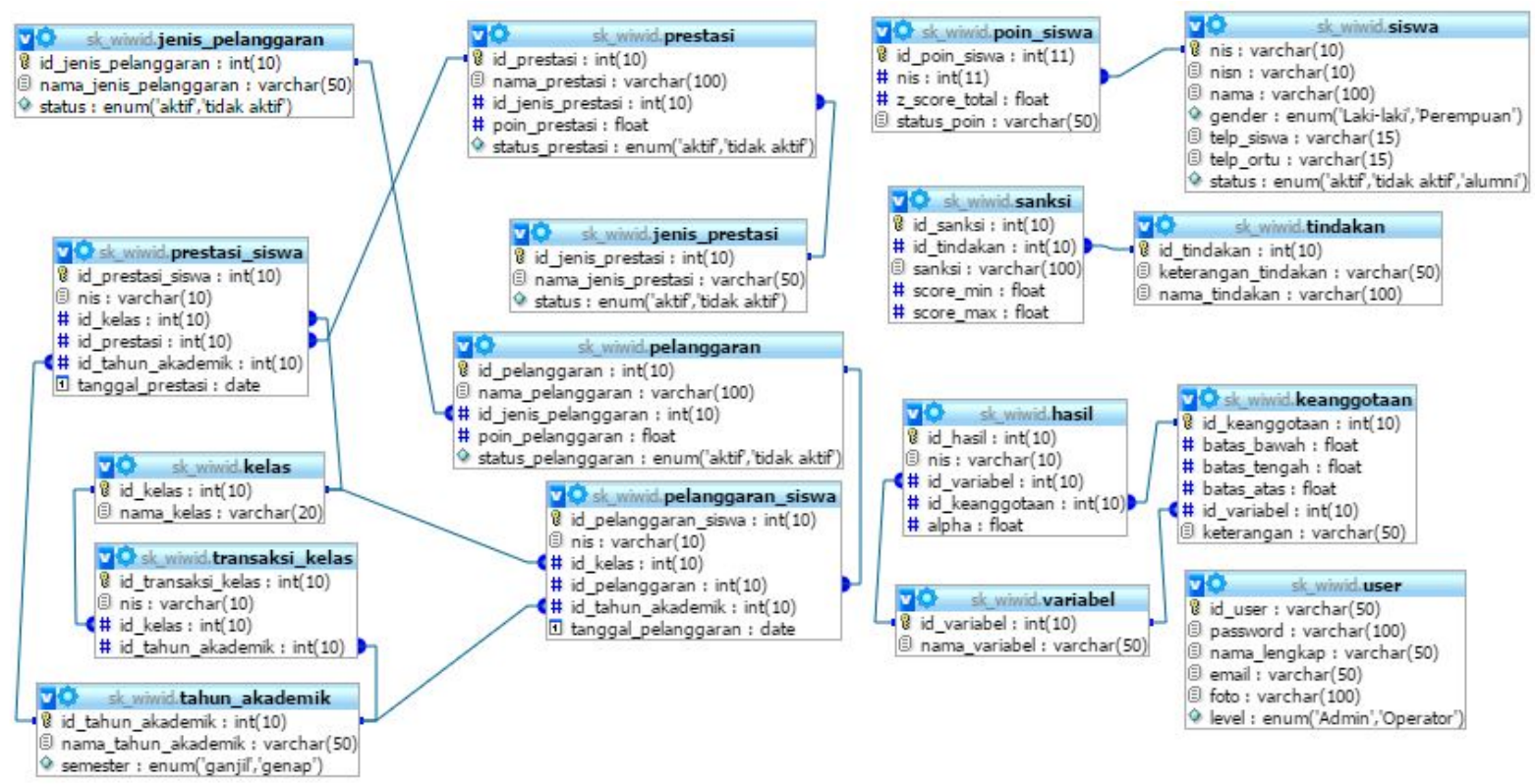

Gambar 4. Relasi Database

\section{PEMBAHASAN}

\subsection{Pengujian Sistem}

Berikut ini contoh pengujian penentuan untuk mendapatkan skor poin pelanggaran menggunakan perhitungan guru bimbingan konseling yang telah dilakukan sebelumnya. Data pelanggaran siswa dapat dilihat pada Tabel 4.
Perhitungan penentuan poin pelanggaran siswa menggunakan perhitungan guru bimbingan konseling sebelumnya.

$$
\begin{aligned}
\text { Skor } & =\text { pelanggaran }- \text { prestasi } \\
& =10-5 \\
& =5
\end{aligned}
$$

Dari hasil perhitungan skor poin pelanggaran dapat disimpukan bahwa tindakan yang didapat oleh siswa adalah Tindakan I.

Tabel 4. Contoh Pengujian

\begin{tabular}{|c|l|r|r|r|r|r|r|l|}
\hline \multirow{2}{*}{ No } & \multirow{2}{*}{ Nama } & \multirow{2}{*}{ Pelanggaran } & \multirow{2}{*}{ Prestasi } & \multicolumn{2}{|c|}{ Manual } & \multicolumn{2}{|c|}{ Ssitem } & \multirow{2}{*}{ Validasi } \\
\cline { 5 - 8 } & & & & Score & Tindakan & Score & Tindakan & \\
\hline 1 & Dairul & 10 & 5 & 5 & Teguran I & 10 & Teguran I & Sesuai \\
\hline
\end{tabular}




\subsection{Pembahasan}

\subsubsection{Proses Fuzzyfikasi}

Proses fuzzifikasi terhadap variabel pelanggaran dibagi menjadi enam himpunan fuzzy dapat dilihat ada Gambar 5.

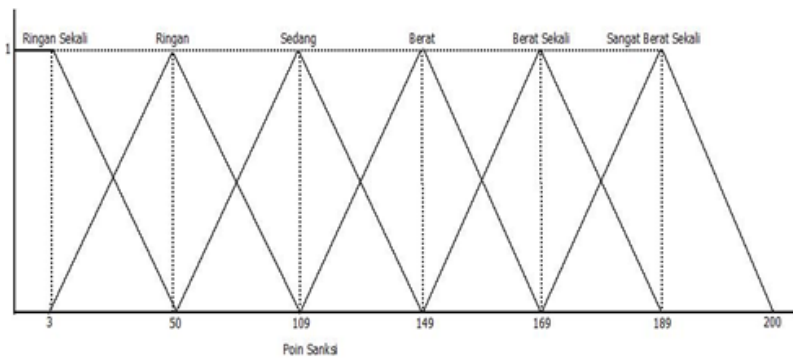

Gambar 5. Variabel Pelanggaran
Proses fuzzifikasi terhadap variabel prestasi dibagi menjadi enam himpunan fuzzy dapat dilihat ada Gambar 6 .

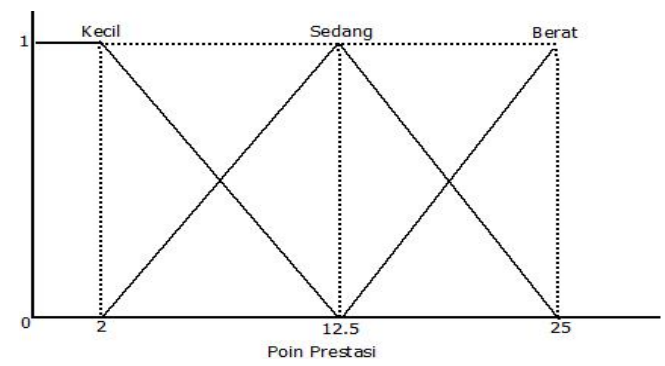

Gambar 6. Variabel Prestasi

Proses fuzzifikasi dengan menggunakan data siswa dapat dilihat pada Gambar 7.

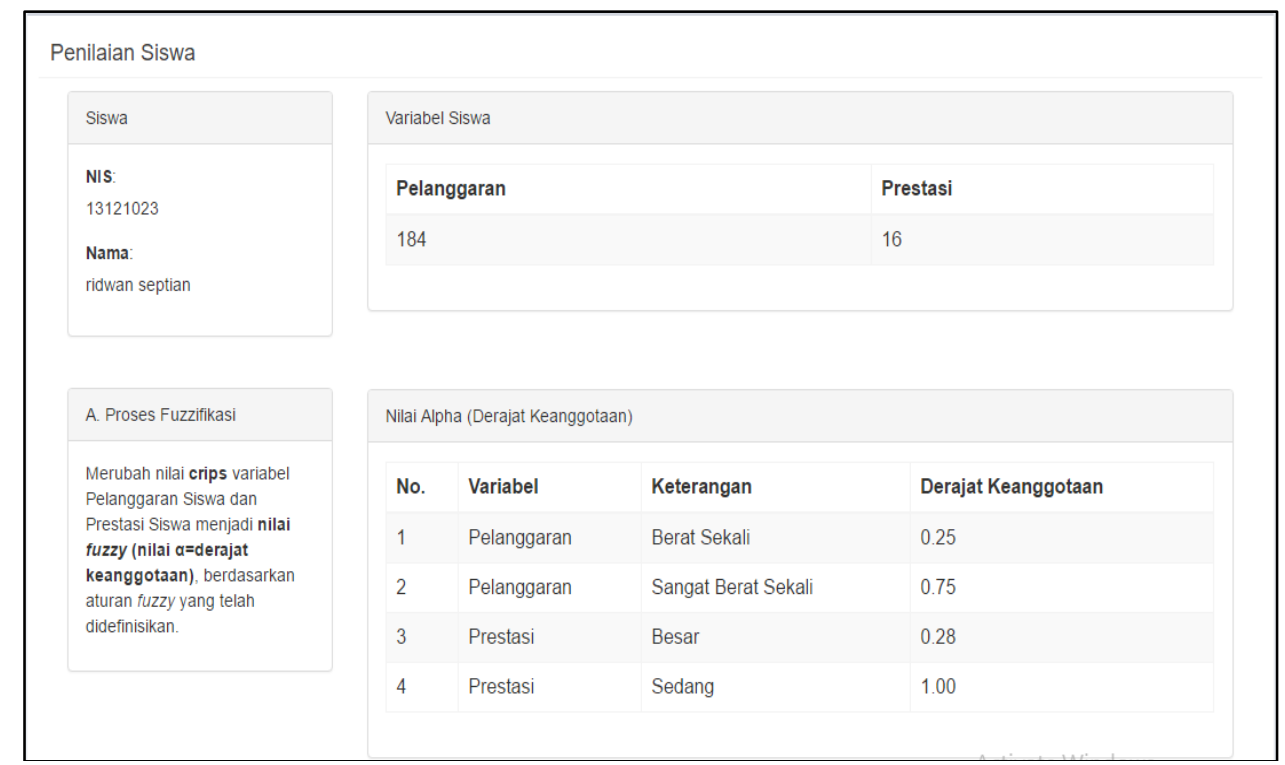

Gambar 7. Fuzzyfikasi Data berikut :

Perhitungan fuzzifikasi adalah sebagai

\section{Pelanggaran}

Pelanggaran dengan poin 184 berada pada himpunan fuzzy berat sekali dan sangat berat sekali. Derajat keanggotaan pelanggaran untuk berat sekali menggunakan rumus :

$\mu$ berat sekali $=189-\mathrm{x} / 189-169(169 \leq \mathrm{x} \leq 189)$

$\mu$ berat sekali $=169-184 / 189-169$

$\mu$ berat sekali $=0.25$

Maka nilai derajat keanggotaan pelanggaran pada himpunan fuzzy berat sekali adalah 0.25.

Untuk himpunan fuzzy sangat berat sekali menggunakan rumus : $\mu$ sangat berat sekali $=\mathrm{x}-169 / 189-169(169 \leq \mathrm{x} \leq$ 189)

usangat berat sekali $=184-169 / 189-169$

$\mu$ sangat berat sekali $=0,75$

Maka nilai derajat keanggotaan pelanggaran pada himpunan fuzzy sangat berat sekali adalah 0,75 .

2. Prestasi

Prestasi dengan poin 16 berada pada himpunan fuzzy besar dan sedang. Derajat keanggotaan prestasi untuk besar menggunakan rumus :

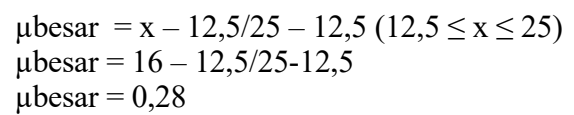

Maka nilai derajat keanggotaan prestasi pada himpunan fuzzy besar adalah 0,28. 
Maka nilai derajat keanggotaan prestasi pada himpunan fuzzy sedang adalah 1,00.

\subsubsection{Proses Inferensi}

Proses inferensi dalam sistem dapat dilihat pada Gambar 8.

Proses fuzzifikasi menghasilkan empat jumlah data yaitu : (1) Pelanggaran berat sekali $=0.25,(2)$ Pelanggaran sangat berat sekali $=$ 0.75 , (3) Prestasi besar $=0.28$, (4) Prestasi sedang $=1.00$.

Dari empat data fuzzifikasi tersebut didapat empat aturan yang dapat diaplikasikan dengan menggunakan aturan Conjunction dengan memilih derajat keanggotaan minimum dari nilai-nilai linguistik yang dihubungkan oleh $(\cap)$ dan dilakukan clipping pada fungsi keanggotaan segitiga untuk menentukan poin pelanggaran siswa :

1. IF Pelanggaran $(0,25)$ AND Prestasi $(1,00)$ THEN Status Poin (Sanksi dan Tindakan) is $(0,25)$

Nilai $Z=154-$ nilai $A Z 14=38,5$

2. IF Pelanggaran $(0,25)$ AND Prestasi $(0,28)$ THEN Status Poin (Sanksi dan Tindakan) is Berat $(0,25)$

Nilai $Z=159$ - nilai $\mathrm{AZ} 15=39,75$

3. IF Pelanggaran $(0,25)$ AND Prestasi $(1,00)$ THEN Status Poin (Sanksi dan Tindakan) is Berat Sekali $(0,00)$

Nilai $Z=149$ - nilai $A Z 17=0$

4. IF Pelanggaran $(0,25)$ AND Prestasi $(0,28)$ THEN Status Poin (Sanksi dan Tindakan) is Berat Sekali $(0,00)$
Nilai $Z=149$ - nilai $A Z 18=0$

\subsubsection{Proses Defuzzyfikasi}

Proses defuzzifikasi menggunakan sistem dapat dilihat pada Gambar 9.

Defuzzifikasi menggunakan model Tsukamoto yaitu mengkonversi himpunan fuzzy keluaran kebentuk crips dengan metode perhitungan rata - rata terbobot :

Keluaran Crips $=\left(\sum(\right.$ Alpha $) \mathrm{x}($ konsekuen $\left.)\right) /\left(\sum(\right.$ Alpha $\left.)\right)$

Keluaran Crips $=(38,50+39,75) /(0,25+0,25)$

Keluaran Crips $=156,50$

Jadi dengan menggunakan metode Tsukamoto, siswa bernama Ridwan Septian dengan poin pelanggaran 184 dan poin prestasi 16 termasuk dalam pelanggaran ringan dengan besar nilai poin 156,50 .

\subsection{Validasi Sistem}

Validasi dengan menunjukkan perbandingan perhitungan guru $\mathrm{BK}$ dibandingkan dengan sistem menggunakan metode fuzzy dapat dilihat pada Tabel 5 .

Tabel keterangan menunjukkan keterangan dari tindakan dan sanksi serta rentang poin yang didapat oleh siswa dapat dilihat pada Tabel 6 .

Berdasarkan hasil pengujian poin siswa menggunakan metode fuzzy Tsukamoto dengan sistem dan perhitungan manual guru BK dengan 40 data uji dihasilkan $73,17 \%$ sesuai dan $26,82 \%$ tidak sesuai.

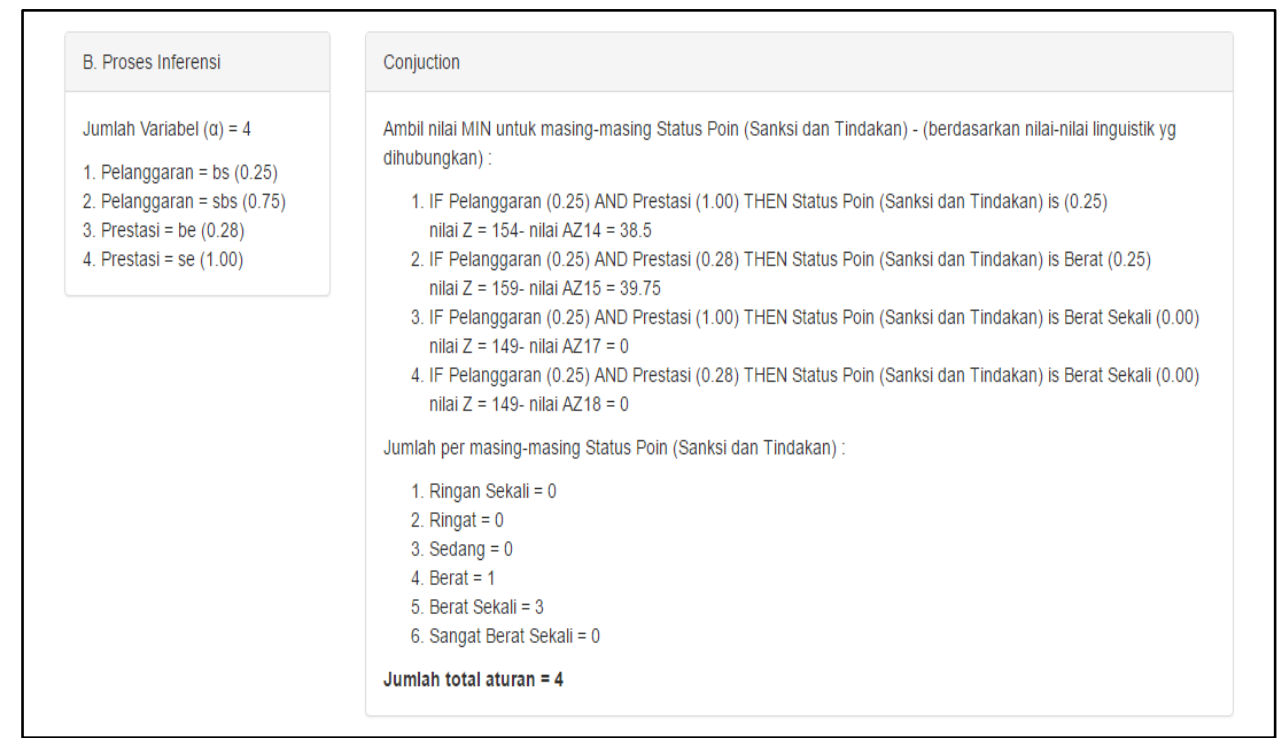

Gambar 8. Proses Inferensi 


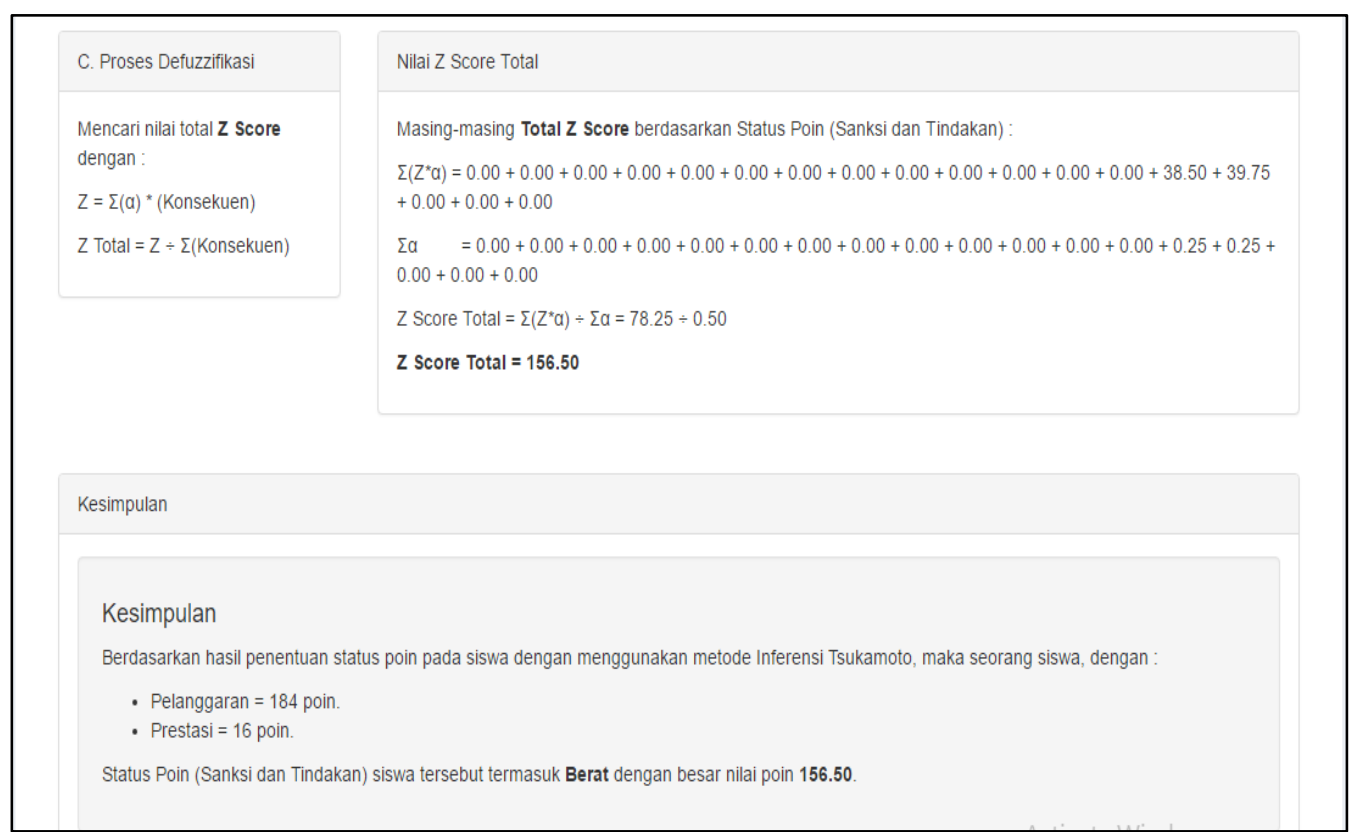

Gambar 9. Proses Deffuzyfikasi

Tabel 5. Validasi Hasil

\begin{tabular}{|c|c|c|c|c|c|c|c|c|}
\hline \multirow{2}{*}{ No } & \multirow{2}{*}{ Nama } & \multirow{2}{*}{ Pelanggaran } & \multirow{2}{*}{ Prestasi } & \multicolumn{2}{|c|}{ Pakar } & \multicolumn{2}{|c|}{ Metode } & \multirow{2}{*}{ Validasi } \\
\hline & & & & Score & Tindakan & Score & Tindakan & \\
\hline 1 & Siswa 1 & 10 & 5 & 5 & Teguran I & 10 & Teguran I & Sesuai \\
\hline 2 & Siswa 2 & 90 & 5 & 85 & Teguran II & 41,64 & Teguran I & Tidak Sesuai \\
\hline 3 & Siswa 3 & 15 & 5 & 10 & Teguran I & 15 & Teguran I & Sesuai \\
\hline 4 & Siswa 4 & 100 & 5 & 95 & Teguran II & 47,13 & Teguran I & Tidak Sesuai \\
\hline 5 & Siswa 5 & 100 & 5 & 95 & Teguran II & 47,13 & Teguran I & Tidak Sesuai \\
\hline 6 & Siswa 6 & 100 & 5 & 95 & Teguran II & 47,13 & Teguran I & Tidak Sesuai \\
\hline 7 & Siswa 7 & 25 & 5 & 20 & Teguran I & 16,43 & Teguran I & Sesuai \\
\hline 8 & Siswa 8 & 25 & 5 & 20 & Teguran I & 16,43 & Teguran I & Sesuai \\
\hline 9 & Siswa 9 & 25 & 5 & 20 & Teguran I & 16,43 & Teguran I & Sesuai \\
\hline 10 & Siswa 10 & 25 & 5 & 20 & Teguran I & 16,43 & Teguran I & Sesuai \\
\hline 11 & Siswa 11 & 25 & 5 & 20 & Teguran I & 16,43 & Teguran I & Sesuai \\
\hline 12 & Siswa 12 & 25 & 5 & 20 & Teguran I & 16,43 & Teguran I & Sesuai \\
\hline 13 & Siswa 13 & 25 & 5 & 20 & Teguran I & 16,43 & Teguran I & Sesuai \\
\hline 14 & Siswa 14 & 95 & 5 & 90 & Teguran II & 47,13 & Teguran I & Tidak Sesuai \\
\hline 15 & Siswa 15 & 75 & 5 & 70 & Teguran II & 47,64 & Teguran I & Tidak Sesuai \\
\hline 16 & Siswa 16 & 75 & 5 & 70 & Teguran II & 47,64 & Teguran I & Tidak Sesuai \\
\hline 17 & Siswa 17 & 75 & 5 & 70 & Teguran II & 47,64 & Teguran I & Tidak Sesuai \\
\hline 18 & Siswa 18 & 75 & 5 & 70 & Teguran II & 47,64 & Teguran I & Tidak Sesuai \\
\hline 19 & Siswa 19 & 75 & 5 & 70 & Teguran II & 47,64 & Teguran I & Tidak Sesuai \\
\hline 20 & Siswa 20 & 75 & 5 & 70 & Teguran II & 47,64 & Teguran I & Tidak Sesuai \\
\hline 21 & Siswa 21 & 10 & 5 & 5 & Teguran I & 10 & Teguran I & Sesuai \\
\hline 22 & Siswa 22 & 5 & 5 & 0 & Teguran I & 5 & Teguran I & Sesuai \\
\hline 23 & Siswa 23 & 5 & 5 & 0 & Teguran I & 5 & Teguran I & Sesuai \\
\hline 24 & Siswa 24 & 10 & 5 & 5 & Teguran I & 10 & Teguran I & Sesuai \\
\hline 25 & Siswa 25 & 10 & 5 & 5 & Teguran I & 10 & Teguran I & Sesuai \\
\hline 26 & Siswa 26 & 5 & 5 & 0 & Teguran I & 5 & Teguran I & Sesuai \\
\hline 27 & Siswa 27 & 5 & 5 & 0 & Teguran I & 5 & Teguran I & Sesuai \\
\hline 28 & Siswa 28 & 5 & 5 & 0 & Teguran I & 5 & Teguran I & Sesuai \\
\hline 29 & Siswa 29 & 10 & 5 & 5 & Teguran I & 10 & Teguran I & Sesuai \\
\hline 30 & Siswa 30 & 5 & 5 & 0 & Teguran I & 5 & Teguran I & Sesuai \\
\hline 31 & Siswa 31 & 5 & 5 & 0 & Teguran I & 5 & Teguran I & Sesuai \\
\hline 32 & Siswa 32 & 5 & 5 & 0 & Teguran I & 5 & Teguran I & Sesuai \\
\hline 33 & Siswa 33 & 10 & 5 & 5 & Teguran I & 10 & Teguran I & Sesuai \\
\hline 34 & Siswa 34 & 1 & 5 & -4 & Teguran I & 0 & Teguran I & Sesuai \\
\hline 35 & Siswa 35 & 10 & 5 & 5 & Teguran I & 10 & Teguran I & Sesuai \\
\hline 36 & Siswa 36 & 10 & 5 & 5 & Teguran I & 10 & Teguran I & Sesuai \\
\hline 37 & Siswa 37 & 5 & 5 & 0 & Teguran I & 5 & Teguran I & Sesuai \\
\hline 38 & Siswa 38 & 1 & 5 & -4 & Teguran I & 0 & Teguran I & Sesuai \\
\hline
\end{tabular}




\begin{tabular}{|c|c|r|r|r|l|r|l|l|}
\hline \multirow{2}{*}{ No } & \multirow{2}{*}{ Nama } & \multirow{2}{*}{ Pelanggaran } & \multirow{2}{*}{ Prestasi } & \multicolumn{2}{|c|}{ Pakar } & \multicolumn{2}{|c|}{ Metode } & \multirow{2}{*}{ Validasi } \\
\cline { 5 - 8 } & & & Score & Tindakan & Score & Tindakan & \\
\hline 39 & Siswa 39 & 1 & 5 & -4 & Teguran I & 0 & Teguran I & Sesuai \\
\hline 40 & Siswa 40 & 10 & 5 & 5 & Teguran I & 10 & Teguran I & Sesuai \\
\hline
\end{tabular}

Tabel 6. Keterangan Tindakan

\begin{tabular}{|c|l|l|l|}
\hline No & Tindakan & \multicolumn{1}{|c|}{ Sanksi } & \multicolumn{1}{c|}{ Poin } \\
\hline 1 & Teguran I & Peringatan Lisan & 3 sampai 50 \\
\hline 2 & Teguran II & Peringatan tertulis, tebusan ke orang tua & 51 ampai 109 \\
\hline 3 & Teguran III & $\begin{array}{l}\text { Pernyataan tertulis, penugasan, orang } \\
\text { tua hadir ke sekolah, pembinaan BK }\end{array}$ & 110 sampai 149 \\
\hline 4 & Sanksi I & $\begin{array}{l}\text { Skorsing selama 2 hari, siswa tidak hadir } \\
\text { di sekolah, pembinaan dari BK }\end{array}$ & 150 sampai 169 \\
\hline 5 & Sanksi II & $\begin{array}{l}\text { Skorsing selama 3 hari, siswa tidak hadir } \\
\text { di sekolah, pembinaan dari BK }\end{array}$ & 170 sampai 189 \\
\hline 6 & Sanksi III & Disarankan untuk mengundurkan diri & 189 sampai 200 \\
\hline
\end{tabular}

\section{KESIMPULAN}

Berdasarkan hasil pengujian yang telah dilakukan dapat disimpulkan :

1. Sistem ini menghasilkan penentuan poin siswa yang dapat digunakan untuk mempermudah dalam penentuan poin siswa.

2. Penentuan poin siswa menggunakan tiga variabel yaitu pelanggaran, prestasi dan sanksi.

3. Pengujian poin siswa menggunakan metode fuzzy Tsukamoto dengan sistem dan perhitungan manual guru BK memiliki hasil $73,17 \%$ sesuai dan $26,82 \%$ tidak sesuai.

Sedangkan saran untuk penelitian selanjutnya yaitu :

1. Pengembangan untuk sistem dapat dikembangkan dengan hasil nilai perhitungan yang lebih spesifik.

2. Sebagai bahan pengembangan untuk penelitian selanjutnya yang berkaitan mengenai penentuan poin siswa.

\section{DAFTAR PUSTAKA}

Arhami, M. (2005). Konsep Dasar Sistem Pakar. Yogyakarta: Andi.

Kamaluddin, H. (2011). Bimbingan Dan Konseling Sekolah. Pendidikan dan Kebudayaan.
Kusumadewi, S., \& Purnomo, H. (2010). Aplikasi Logika Fuzzy Untuk Pendukung Keputusan. Yogyakarta: Graha Ilmu.

Priyolistiyanto, A., \& Saefan, J. (2014). Aplikasi Sistem Informasi Bimbingan Dan Konseling Dengan Menggunakan Metode Forward Chaining. Prosiding Mathematics and Sciences Forum.

Setiawan, N. S., Jusak, \& Lemantara, J. (2013). Sistem Pakar Mendiagnosis Kecerdasan Majemuk Menggunakan Metode Fuzzy Expert System. Sistem Informasi, 72-76. Dipetik 10 15, 2016, dari Sistem Pakar Untuk Mendiagnosis Kecerdasan Manjemuk Menggunakan Metode Fuzzy Expert System: http://jurnal.stikom.edu/index.php/jsika

Syah, M. M., \& Gunawan, A. (2016). Sistem Pakar Bimbingan Konseling Siswa Dengan Metode Certainy Factor Berbasis Web Pada SMAN 1 Cikembar. SNIPTEK, ISBN : 978-602-72850-3-3.

Thamrin, F., Sediyono, E., \& Suhartono. (2012). Studi Inferensi Fuzzy Tsukamoto Untuk Penentuan Faktor Pembebanan Trafo PLN. Sistem Informasi Bisnis.

Wana, \& Winiarti, S. (2013). Sistem Pendukung Keputusan Penentuan Sanksi Terhadap Siswa Yang Melanggar Peraturan Akademik Sekolah Metode Fuzzy Logic. Informatika. 
26 Jurnal Multimedia \& Artificial Intelligence, Volume 1, Nomor 2, Agustus 2017 